Journal of Southeast Asian

\title{
[Special Issue on Hmong Newcomers to Saint Paul Public Schools] The Affective Consequences of Cultural Capital: Feelings of Powerlessness, Gratitude, and Faith among Hmong Refugee Parents
}

Bic Ngo

University of Minnesota, bcngo@umn.edu

Follow this and additional works at: https://docs.lib.purdue.edu/jsaaea

Part of the Asian American Studies Commons, and the Bilingual, Multilingual, and Multicultural Education Commons

\section{Recommended Citation}

Ngo, Bic (2008) "[Special Issue on Hmong Newcomers to Saint Paul Public Schools] The Affective Consequences of Cultural Capital: Feelings of Powerlessness, Gratitude, and Faith among Hmong Refugee Parents," Journal of Southeast Asian American Education and Advancement. Vol. 3 : Iss. 1, Article 4.

DOI: $10.7771 / 2153-8999.1100$

Available at: https://docs.lib.purdue.edu/jsaaea/vol3/iss1/4

This document has been made available through Purdue e-Pubs, a service of the Purdue University Libraries. Please contact epubs@purdue.edu for additional information.

This is an Open Access journal. This means that it uses a funding model that does not charge readers or their institutions for access. Readers may freely read, download, copy, distribute, print, search, or link to the full texts of articles. This journal is covered under the CC BY-NC-ND license. 


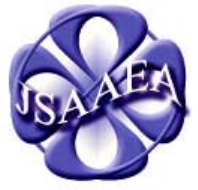

Volume 3 (2008)
Journal of Southeast Asian American

Education \& Advancement

WwW.JSAAEA.org
A peer-reviewed

scholarly journal

published by the

National Association

for the Education \&

Advancement of

Cambodian, Laotian, and Vietnamese

Americans (NAFEA)

\title{
Special Issue on Hmong Newcomers to Saint Paul Public Schools
}

\section{The Affective Consequences of Cultural Capital: Feelings of Powerlessness, Gratitude and Faith among Hmong Refugee Parents}

\author{
Bic Ngo \\ University of Minnesota
}

\begin{abstract}
In education research, the analysis of the role of cultural capital has focused primarily on its role in parent involvement. Little attention has been paid to how cultural capital affects the attitudes or feelings of parents about their worth and roles as parents. In this article I examine the impact of the exclusionary characteristic of cultural capital on refugee Hmong parents from Wat Tham Krabok. I highlight themes of uncertainty, powerlessness, gratitude and faith that parents repeatedly raised when speaking about their children's education. I suggest that paying attention to the affective-emotional-consequences of cultural capital is critical for understanding the outlook of refugee Hmong parents on their children's education.
\end{abstract}

Beginning in the spring of 2004, approximately 15,000 Hmong refugees were relocated to the United States (Hang et al., 2004) ${ }^{1}$. These Hmong refugees were part of an estimated 40,000 living in an unauthorized camp located on the grounds of Wat Tham Krabok (WTK), a Buddhist temple 90 miles from Bangkok (Grigoleit, 2006; Hang et al., 2004). Of the refugees who were relocated to the United States approximately 5,000 came to Saint Paul, Minnesota (Hang, et al., 2004), part of a metropolitan area estimated to have the largest urban Hmong population in the world (Minneapolis Foundation, 1999). The WTK Hmong refugees were unique in that 52\% of the residents were younger than fifteen years old (Hang et al., 2004). This refugee population was also distinctive in that educational opportunities were available to less than half of the children and very few adults (Hang et al., 2004).

The limited education of Hmong adults from WTK is not unlike the majority of the Hmong population in the United States. According to the 2000 U.S. Census, 59\% of Hmong Americans ages twenty-five and over have less than a high education. In addition, Census figures reveal that 35.1\% of Hmong households are "linguistically isolated." In these households no one over the age of fourteen speaks only English or speaks a non-English language and English "very well.” In other words, all members of the household over fourteen have some difficulty speaking

\section{@)}

SOMERIGHISRESERNEDReaders are free to copy, display, and distribute this article, as long as the work is attributed to the author(s) and the Journal of Southeast Asian American Education \& Advancement, it is distributed for noncommercial purposes only, and no alteration or transformation is made in the work. More details of this Creative Commons license are available at http://creativecommons.org/licenses/by-nc-nd/3.0/. All other uses must be approved by the author(s) or JSAAEA. 
English (U.S. Census, 2000). For WTK parents, their limited experience with formal education in general and with U.S. institutions in particular resulted in a dependence on relatives, friends, and school district staff in decisions pertaining to their children's education (Bigelow, et al., 2005).

This article examines the consequences of the inexperience of WTK Hmong parents with formal education in general and educational institutions in the United States in particular. It reveals that their limited experience with schools, unfamiliarity about the roles of students, teachers, school staff, and their roles as parents have practical consequences for understanding and engaging in their children's education. Moreover, and significantly, it explicates the emotional toll on parents who are unable to help themselves and their children.

In the next section, I review the literature on cultural capital and education, highlighting research with immigrant parents. I then outline the methods used in this study. I then present my research findings, integrating into this analysis a discussion of research on the school experiences of immigrants (especially Hmong and Southeast Asian) and parent involvement. I conclude by offering directions for research on cultural capital and Hmong immigrant parents.

\section{Cultural Capital and Education}

Educational researchers interested in how schools reproduce existing social inequalities often turn to the concept of social reproduction. The work of French sociologist, Pierre Bourdieu $(1977,1986)$ on cultural capital has especially contributed to the social reproduction perspective. As Lee and Bowen (2006; see also Bourdieu, 1986; Olneck, 2000; Robbins, 2000) pointed out, for parents cultural capital in education exists in three forms:

personal dispositions, attitudes, and knowledge gained from experience; connections to education-related resources (e.g., books, computers, academic credentials); and connections to education-related institutions (e.g., schools, universities, libraries). (p. 197)

Similarly, Olneck (2000) drew on Bourdieu's work to detail three forms of cultural capital:

First, cultural capital is embodied in styles and manners and in modes of bearing, interaction, and expression. It is also embodied in cultural preferences and affinities, in apparently intuitive responses to valued distinctions and institutional expectations, and in ease and facility with valued ways of knowing and reasoning and with valued schemes of appreciation and understanding. Finally, it is embodied in the command of valued cultural knowledge (p. 219).

The "capital” obtained through having certain cultural background, knowledge, dispositions, and skills play a central role in academic success and failure.

As explained by Bourdieu (1977), cultural capital—socially valued "highbrow" behavior and knowledge (e.g., reading literature, attendance at theaters, concerts, and museums, and/or interest in art and classical music) - is more likely to manifest itself in families of high socioeconomic status. Schools legitimate this culture of the dominant classes by systematically rewarding that of dominant upper-and middle-class groups while devaluing the cultural capital of those from low-income backgrounds (Bourdieu, 1977). Educational success for students 
Ngo: The Affective Consequences of Cultural Capital

"depends upon the previous possession of the instruments of appropriation” (Bourdieu, 1977, p. 493-4; emphasis added).

Educational institutions implicitly demand that everyone possess the linguistic and cultural competence that it does not provide:

By doing away with giving explicitly to everyone what it implicitly demands of everyone, the educational system demands of everyone alike that they have what it does not give. This consists mainly of linguistic and cultural competence and the relationship of familiarity with culture which can only be produced by family upbringing when it transmits to the dominant culture (Bourdieu, 1977, p. 494).

For those who do not have the background knowledge or upbringing required by U.S. educational institutions, navigating the educational process is that much more challenging. Parent involvement and academic success and failure is thus less about commitment to education and natural talents and more about social class background (Lareau, 1989; Lareau \& Horvat, 1999; Vincent et al., 1999).

As numerous researchers have pointed out, parents who understand and share the same middle-class values of schools are better able to assist in their children's education (Fine, 1993; Lareau, 1989; Lareau \& Horvat, 1999). However and problematically, the "codes" or "familiarization" that would enable parents to assist their children "belong only to those who have acquired culture or, at least, the dispositions necessary for the acquisition of academic culture, by means of familiarization” (Bourdieu, 1977, p. 495).

The exclusionary character of cultural capital leads to "moments of exclusion" (Lareau \& Horvat, 1999). Within the context of schools, parents' differing notions and experiences with education affect their perceptions of their roles as parents and the roles of students, teachers, and school staff. In turn, this has deep ramifications for children's academic achievement. For example, we know from Smith-Hefner (1999) and Um's (1997) research with Cambodian students and parents that parents have different understandings of social hierarchy. One result of this different understanding of appropriate social relations is a reluctance by Cambodian parents to question school teachers and staff. Additionally, parents who are not familiar with educational practices such as fundraisers, "back to school” nights, PTA/PTOs, or volunteering in schools, are less able to assist their children or be "involved" in their education (Lopez, 2001; Pomerantz et al., 2007). Other research has revealed that some parents have limited ideas about career options, the role and importance of extracurricular activities, or the process of college admissions. This results in situations where parents pressure children to pursue careers in medicine or law (Um, 2003), disapprove of participation in school extracurricular activities (Um, 2003), or remain uninvolved in the college application (e.g., financial aid, college placement exams, college choice) process (Ngo, 2000; Teranishi, 2004). ${ }^{2}$

In education research, the analysis of the role of cultural capital has focused primarily on its role in parent involvement. In large part, this is because parent involvement has been shown to be associated with children's academic performance (Lee \& Bowen, 2006). The focus on parents within the "parent involvement" research has focused on involvement as a "scripted role to be 'performed"” (Lopez, 2001, p. 417) and on the quantity of involvement (e.g., number of parents, time invested in activities) (Pomerantz et al., 2007). General parent involvement research has especially been about whether parents are attending parent-teacher conferences, attending children's school activities, volunteering in children's schools, assisting children with 
homework, or talking to children about school (Fan \& Chen, 2001; Jeynes, 2003; Lee \& Bowen, 2006). The few studies that have focused on immigrant parent involvement (see, e.g., Collignon et al., 2001; Delgado-Gaitan, 2004; Garcia Coll et al., 2002; Valdes, 1996) particularly point to the cultural capital in English-language-proficiency and knowledge about school structures that are barriers to immigrant parent involvement. Taken together, this research demonstrates the ways cultural capital has practical consequences for parent involvement, because it limits the ability of parents to participate in their children's education. Little attention has been paid to the affective consequences - the ways cultural capital influences the attitudes or feelings of parents about the roles of schools and teachers and their worth and roles as parents.

In this article I reveal the practical consequences of cultural capital on refugee Hmong parents from Wat Tham Krabok. Moreover and significantly, I also demonstrate the affective or emotional consequences of cultural capital on the outlook of refugee Hmong parents about their children's education. I highlight themes of uncertainty, powerlessness, gratitude and faith that parents repeatedly raised when speaking about their children's education.

\section{Methodology}

This article draws on research from a larger evaluation study of the Transitional Language Centers set up by the Saint Paul Public Schools to assist with the language transition of Wat Tham Krabok (WTK) students. This article focuses on the experiences of WTK Hmong parents with their children's education. The guiding questions for this article include: a) How did cultural capital influence Hmong parents' experiences and perspectives on their children's education? and b) What were the emotional or affective effects of cultural capital on Hmong parents?

Data for this article come from focus group interviews (Krueger \& Casey, 2000) with Hmong parents that assessed their experiences with the language programs at three Transitional Language Centers (TLCs) and two Language Academy (LAs) where their young children attended elementary school. I hired and trained a Hmong bilingual community member to assist me with this project. I trained the assistant on how to recruit participants and conduct the interviews. This Hmong bilingual assistant recruited the parents through phone calls and conducted the focus group interviews in Hmong. Having a research assistant collect the data for this study was important because I wanted to provide the new refugee Hmong parents with a forum where they could speak candidly about their experiences. With this in mind, I consciously selected a Hmong bilingual assistant who was not affiliated with the school district or university. This assistant also had over fifteen years of experience working with Hmong new arrivals in a social service setting.

The refugee Hmong parents were recruited from a list provided by the St. Paul Schools. This list included all Wat Tham Krabok parents with children in the five elementary schools. With the assistance of the school district, transportation was provided for the parents to attend the focus groups. The five focus groups included an average of eight parents, with a total of thirty-eight parents participating in the study. The parent participants included eighteen fathers and twenty mothers. To thank them for their time, the parents were given a gift certificate honorarium of $\$ 20$ to Target stores.

The five focus group interviews took place in the evening at a Hmong social service agency familiar to the Hmong parents. The audio-recorded interviews lasted approximately one and a half hours. Hmong parents were asked questions pertaining to several aspects of their 
experiences with their children's education at the TLCs and LAs, including program logistics, school atmosphere, language instruction, and teaching. The interviews were transcribed and translated by the Hmong bilingual research assistant. These interview transcripts were coded in a two-step process (Emerson, Fretz \& Shaw, 1995). I first coded line-by-line to identify and flesh out all possible ideas or issues (Miles \& Huberman, 1994). In the second phase of coding and analysis, the transcripts were analyzed and coded a second time, focusing on specific topics that I identified as especially of interest (Miles \& Humberman, 1994). This article draws on this more focused set of ideas (Strauss \& Corbin, 1998; Wolcott, 1994).

While the bilingual research assistant was essential to the study, I recognize the reliance on an assistant for data collection due to language obstacles increases the limitations of the study. Nevertheless, as one of few studies that focuses on the perspectives of Hmong parents, this research makes a considerable contribution to the field of Southeast Asian American education. It points to ways forward for future research with Hmong and other Southeast Asian parents.

\section{Practical Consequences}

The overarching message that the refugee Hmong parents conveyed in the focus group interviews was appreciation for the assistance and work of teachers and staff. They were grateful for efforts such as the language assistance provided by the Transitional Language Centers and Language Academies, efforts by teachers to communicate with them via letters and phone calls, and initiative by teachers to make appointments with them to discuss their children's progress. Parents also pointedly commented on the respect teachers showed them and their children in contrast to their poor treatment in Thailand (Bigelow et al., 2005; Grigoleit, 2006). Despite the expressions of appreciation for the efforts of the school district, teachers and staff, the accounts of parents about their experiences with their children's education included an undercurrent of uncertainty and fear.

According to Grenfell and James (1998) cultural capital "should be understood in terms of its practical consequences” (p.22). For parents who want to engage in their children's education, not having the obligatory cultural capital to navigate educational institutions is a significant disadvantage (Lareau, 1989; Vincent et al., 1999). The "practical consequences" of lack of experience among immigrant parents with U.S. institutions and practices may manifest in a variety of ways. This includes not knowing about the array of career paths available to their children beyond professions in medicine or law (Maira, 2002; Um, 2003), being able to help children with homework (Gibson, 1988), understanding the importance of extracurricular activities (Um, 2003), or knowing about the prestige differences among colleges and universities, or about admissions details such as fee waivers, financial aid, or standardized admissions tests (Ngo, 2000; Gandara, 1995). Critical decisions such as college choice are made by children on their own, with the assistance of school staff, or with the help of older siblings and friends (Ngo, 2000; Teranishi, 2004).

\section{Not Knowing}

For the refugee Hmong parents, their inexperience with U.S. schools resulted in "practical consequences" such as not being able to help children with homework and not knowing the meaning of grades. As articulated by one parent, "Homework is one of the biggest concerns for the kids like math problems, reading and science. Before the kids can do anything at all they 
have to be able to read and understand English first. No one at home can help.” During the focus group interviews, parents repeatedly inquired about homework assistance as well as additional tutoring programs to help their children, since they were unable to do so (Bigelow et al., 2005). In addition to homework, another specific issue of concern for the parents included the meaning of grades on report cards. Despite multiple conversations with teachers, the refugee Hmong parents struggled with understanding grades:

They do give us report cards and we really don't know how to read them. They only do ABC's and what does it mean? We don't know how to interpret them. I have talked to the Hmong teachers a couple times but they said the same thing. They can't really give us a better reason why.

This concern about not really knowing how well their children were doing was reiterated by other parents. One parent even used understandings of how grades worked in Laos and Thailand as a reference point:

I would like to know how well they are doing. Is this child ahead of the class or behind? Whenever we go to the conferences they always say that he or she is doing well. But sometimes I see that they are struggling and not doing well. So I would like to know where exactly they rank. For example, in Laos and in Thailand they rank by percent if they rank at $60 \%$ and up meaning they are at the passing grade. But if they are under $50 \%$ meaning they fail. This is exactly what we want to know.

As this excerpt reveals, the expectations of refugee parents for U.S. practices were informed by their experiences with educational institutions in Thailand. While this knowledge may afford them with cultural capital to navigate schools in Thailand, it is less helpful for the U.S. context.

The Hmong parents in all of the focus groups were painfully aware that they did not have the experience and skills to support their children's education. They made remarkably insightful comments about their ability to assist their children. One parent particularly commented on how their lack of formal education made them dependent on the advice of relatives when choosing schools for their children: "Some of us have never gone to a formal school and know very little about the education system. It was hard to for us to make that decision.” Another parent echoed this sentiment: "We don't know the education system in this country well enough to know to tell what the right thing is and what the wrong thing is." Indeed, as a parent pointed out, because they have had no experiences with schools themselves, they really do not know what to expect: "We don't know how many programs total this school has for our children. Many of us have never gone to school and we don't know the school system well enough to know what a school should have." Not knowing the school system not only means not knowing what to expect, but also not knowing what questions to ask: "Later when we are able to speak more English and have a better understanding of the school system. I am sure we'll have more questions and know what to ask."

These comments poignantly reveal the lack of knowledge about and inexperience with U.S. schools. They are significant because they point to the way cultural capital positions them as non-knowers. But moreover, the comments highlight the difficulty refugee parents have with being engaged in their children's education, and as advocates for their children. As a researcher seeking to understand the perspective of parents on the effectiveness of the Transitional 
Language Centers set up by the Saint Paul Public Schools, it became clear that not knowing how schools work in the United States meant not knowing "what the right thing is and what the wrong thing is." Not knowing what to expect out of schools means not knowing when to intervene in their children's education.

\section{Affective Consequences}

This study echoes the findings of other research by revealing the "practical consequences" of cultural capital on Wat Tham Krabok refugee Hmong parents. Furthermore, it also became clear to me that cultural capital has affective consequences. The Hmong parents conveyed the emotional outcomes of not knowing the cues and codes necessary to navigate our schools and community. Being new to systems and structures of the United States had an emotional toll on the parents that went beyond the practical implications of "not knowing." In the following, I underscore the emotional or affective consequences of cultural capital on the feelings parents had about themselves and their roles in their children's education.

\section{Powerlessness in the Face of Change}

Similar to the experiences of previous refugees, the process of resettlement is transforming social structures, gender and generational roles and power relations within the Hmong family and community. Parents commented on the changes their children were undergoing, as they were exposed to English language and U.S. schools and customs. Speaking about the role of schools in the children's cultural transformation, one parent remarked, "From when they first arrived until now my children are different. They are thinking differently and they are learning. They are learning English and advancing more than us." The comments that children are "thinking differently" and "advancing more than us" point to concerns about how education will affect relationships with their children. Parents were especially concerned about the cost of the acquisition of English proficiency to their children's ancestral language (Um, 1997), and the implications this had for intergenerational communication. To emphasize the veracity of their fears, parents pointed to the effects of acculturation on relatives and their children: "We are scared because we see the other kids that came before us and they cannot even hold a conversation with us." These comments point to feelings of fear as an affective outcome of cultural capital. Parents fear that they will be left behind by their children's advancement, and worried about what changes would do to the relationships with their children.

For the parents, the school was a primary site of change, and contributed immensely to the transformations in their children (Kibria, 1993). Parents reported how their children used to be scared but now are getting used to things. As one parent articulated, "My kids are changing everyday because they are now learning. They use to be scared at first because they don't know the language and maybe it's just that they haven't get use to the new school yet." Fears about the changes they saw in their children were made apparent in comments such as: "They change too fast and that sometime it is scary." Simultaneously, the rapid ways in which children adjusted to the United States was observed as different from the rate of adjustment among adults: "Kids adjust to new things a lot faster than the older people." Children's rapid acquisition of knowledge is already creating rifts in communication between parents and children (Kibria, 1993; Um, 1997). As parents from one group shared, "They really don't say much to us parents. They speak a lot of English now." "If you ask them too many questions sometime they begin to get irritated." 
In the span of one academic year, the acquisition of new knowledge, skills, and English language_-cultural capital_among Hmong children already transformed parent-child relations (Donnelly, 1994; Faderman, 1998). As children are learning about the differences and disparities between their families and other families who have been in the United States longer, they are blaming their parents for their lack of cultural and economic capital. Parents shared that kids are "blaming us, the parent, that came to America so late. That is why they are not good like other kids." Likewise, another parent remarked, "One of my kids scold at us for coming too late and now he is mixed in with older kids and that he can't learn as fast." Additionally, parents also noted that their children "feel so shameful for many reasons." One cause for shame included material things that other kids have that their parents cannot provide for them (Kibria, 1993). As a parent painfully shared, "With a couple of my kids they complain about not having enough better clothes and shoes to wear like other kids who have been here before."

As the literature on immigrants has revealed, the relatively faster rate of acculturation of youth gives them significant power and responsibility at the same time that it disempowers adults (Donnelly, 1994; Kibria, 1993; Zhou \& Bankston, 1998). Echoing this research, the refugee Hmong parents conveyed an overwhelming sense of powerlessness to help themselves and their children. For example, one parent said, “Sometimes I feel I am worthless because I can't really help any of my kids, instead they are the ones that help me." Significantly, an affective consequence of cultural capital includes a sense of "worthlessness" among refugee Hmong parents. Without prior experience with U.S. schools, English language proficiency, and other background knowledge, parents are dependent on the goodwill and knowledge of adult relatives, school staff as well as their young children for decisions about school and everyday life. This dependence has critical implications for about the ways parents perceive themselves and their roles in their children's education.

Implicitly, schools may be sending the message to refugee Hmong parents that they cannot help in their children's education. For example, parents shared that they were not asked to volunteer in their children's schools or classrooms. Tellingly, they were not surprised that they were not asked, pointing out that they do not have knowledge or skills that would be useful in the classroom. As one parent commented, “We don’t write and speak any English. How can we help? We can probably help set up and clean up after an event like New Year's or any other event that does not require English." In the Transitional Language Centers and Language Academies, where bilingual assistance was available-even abundant (Bigelow, this issue; Bigelow et al., 2005)—classroom lessons that integrated the "funds of knowledge" (Gonzalez et al., 2005; Moll \& Gonzalez, 2003) of Hmong refugee parents might have sent parents and their children the message that parents are knowledgeable and able to contribute to their children's education. Instead, the exclusion of the parents contributed to their sense of worthlessness and helplessness. As one parent said, “I don't know any English and I can't read or write so how am I going to help my kids?” Comments that they cannot help their children also included sentiments of anguish and grief. For example, one parent remarked, "English is very hard and they scold at us sometimes for not being able to help.” Another parent said, "We adults have now turned into kids." Yet another parent from a TLC group said, "What can I do to help my kids with my limited skills?” Unfortunately, the subtractive understanding of the abilities of parents (Valenzuela, 1999) of well-meaning schools and teachers precluded a two-way relationship between parents and schools, where the knowledge of parents may be integrated into school and classroom practices. The affective consequences on parents included helplessness, worthlessness, anguish, and grief that they cannot assist their children. 
Ngo: The Affective Consequences of Cultural Capital

\section{Gratitude and Faith in the System}

The amenities standard to U.S. society ranging from public schools, indoor plumbing and electricity are luxuries compared to the refugee camps where Hmong families have lived for years (Grigoleit, 2006; Hang et al., 2004). This frame of reference played a significant role in the perceptions and expectations of U.S. schools and teachers among the parents. They spoke at length about the poor treatment of them and their children by teachers in Thailand (Bigelow et al., 2005) and repeatedly expressed gratitude for the assistance from the school district, teachers, and staff. ${ }^{3}$ Coming from a context of a refugee camp where formal schooling was available only to a few families with enough money to send their children to Thai schools (Hang et al., 2004), the Hmong parents were happy that their children were able to simply go to school for free. As a parent shared, "We were happy that the school accepted our children and happy that they are receiving an education [everyone nods and agrees]." Another comment included: "We are very thankful to have come to this country and to have all the Hmong and the non-Hmong teachers help our children.” In addition to gratitude, Hmong parents talked about the hope they had for their children in the United States, in light of the suffering they have endured (cf. Carreon et al., 2005). As one parent put it, "We have suffered enough all our lives and we want our children to have a better life now that they are here."

The combination of parents' prior refugee experience, experience with Thai schools and lack of experience with U.S. schools may be contributing to an idealistic, potentially problematic faith in schools and teachers. The lack of cultural capital among Wat Tham Krabok parentsparticularly their inexperience with the school system and understanding of appropriate roles and social relations between school personnel and parents-may be preventing them from raising questions or concerns to school teachers and staff (Phommsasouvanh, 1997; Smith-Hefner, 1999; Um, 1997). The parents repeatedly expressed fear of bothering school teachers and staff with problems related to their children's education. For example, in the experiences of one mother, one of her children was placed in the wrong grade. She and her husband did not do anything for several months, and finally took her out of the school close to the end of the academic year. When she talked about the school's mistake, she said, "We really don't mind but I just wanted to tell you." Similarly, another parent shared:

One of my kids got teased a lot because of how she walks. This child of mine when she walks she has a gimp and they may think she's funny and she gets so stressed out over all of this until she doesn't want to go to school. I spoke to one of my sisters, she told me to go straight to the school principle but I did not want to because it might not look good for all the Hmong parents to make such a report. The only thing I can do is talk nice to her and will continue to encourage [her] (emphasis added).

These remarks point to the ways the affective consequences of cultural capital (in this case gratitude) may influence the actions and decisions parents make about their children's education. The reluctance by the Hmong parents to question authority or engage in confrontations with teachers or principals regarding their children's education is an emotional outcome of cultural capital. The above remarks suggest that cultural capital in the form of "personal dispositions, attitudes, and knowledge gained from experience” with U.S. schools (Lee \& Bowen, 2006, p. 197) may be influencing the ability of Hmong parents to advocate for their children. While 
parents with cultural capital may directly call on a school principal to address problems, refugee Hmong parents were concerned that doing so might reflect poorly on all Hmong parents.

In addition to a reluctance to report problems to school personnel, the affective consequences of cultural capital included a general feeling of faith in the system in regard to the quality and outcome of their children's education. In particular, the Hmong parents expressed the belief that U.S. schools and teachers will do their best to teach their children how to be successful. Their lack of knowledge of how schools work and their roles as parents was ultimately allayed by faith in the teachers. As one parent put it, "We don't really know, but we have faith in the teachers and that our children will receive a good education. We are very happy for them to be in school.” Another parent added:

We are those people that have no country, we move from place to place for the last 40 to 50 years. We never had the chance to go to school and also came to the United States. When we are old we don't have any of the ability and skills to help our kids. Right now we put $100 \%$ on the teacher to educate our children (emphasis added).

In the same vein, another parent remarked, "We don't know what the school does to protect our children but we put our faith in them to help our children stay on the right path." Significantly, this faith that schools will protect their children and help them "stay on the right path" was voiced in terms of their belief and understanding of the role of teachers as parents (cf. SmithHefner, 1999). In a telling remark, another parent said, “There isn't a thing that we don’t like. They teach and help our children to be smart. We consider they are parents to our children so we have no complaints at all [all parents agree]" (emphasis added). As an affective consequence of cultural capital, trust in the system is shaping the decision of refugee Hmong parents to leave their children's education in the hands of teachers.

\section{Conclusion}

Speaking about the role of cultural capital in academic performance and attainment, Jay McLeod (1987) compared schools to "trading posts," where cultural capital is the currency used in the negotiation of academic credentials. As McLeod cogently put it:

Schools serve as the trading post where socially valued cultural capital is parlayed into superior academic performance. Academic performance is then turned back into economic capital by the acquisition of superior jobs. Schools reproduce the social inequality, but by dealing in the currency of academic credentials, the educational system legitimates the entire process. (p. 14)

Educational institutions demand that parents from low-income and immigrant backgrounds have the requisite cultural capital. Institutional and pedagogic practices require that all students should be familiar with the codes of the dominant culture. By dealing in the currency of dominant, middle- to upper-class society, schools exclude parents from low-income, immigrant backgrounds. Simultaneously, schools impugn parents and position them as parents who "Just don’t care” (Lightfoot, 2004).

As my research with Hmong parents from Wat Tham Krabok has illustrated, cultural capital not only has practical consequences (Grenfell \& James, 1998), but also affective 
repercussions. By requiring that all parents possess the dispositions, skills, and experiences of parents from dominant groups, schools contribute to the emotional denigration of refugee Hmong parents who are already struggling with the loss of power and other challenges of adapting to U.S. society. In schools, the terms of involvement for parents are already defined by limited power (Fine, 1993). For WTK parents, these constraints are amplified, as the reverberations of cultural capital manifests in affective outcomes of fear, uncertainty, and powerlessness among Hmong parents.

In the case of the refugee parents in this study, they blamed themselves for being unable to help with their children's education. As they resigned themselves to positions of unknowledgeable and unskilled, they placed their trust in teachers and schools. What this meant for Hmong parents was an attitude of reliance that schools and teachers "know best," rather than one of participation and input in their children's education. Ultimately, the affective impact of cultural capital, subtle and frequently overlooked, may mask the ways school policies and practices compel parents to be un-involved.

While research on the practical consequences of cultural capital for educational attainment and parent involvement has been important, my research with Hmong refugee parents points to the need to closely examine the impact of cultural capital on the emotions and attitudes that parents have about their worth and roles as parents. We need research with Southeast Asian and other immigrant parents that asks: How does faith in teachers impact parent participation in children's education? How do the perceptions of skills, power, and knowledge of parents affect their involvement? and In what ways do parent involvement policies and practices engage knowledge and skills of parents? These questions are important, because when parents feel they are powerless, worthless, or unknowledgeable, school's efforts to structure and promote "involvement" may prove to be in vain. Likewise, notions of "parent involvement" that do not include the views of parents about their self worth and roles in their children's education is deeply deficient. Research on the affective consequences of cultural capital is thus critical for understanding issues related to parent involvement in general. Further research on the affective consequences of cultural capital will help transform the terms and conditions by which immigrant parents are involved in the work of schools and teachers (Fine, 1993; Carreon et al., 2005).

\section{Endnotes}

${ }^{1}$ For further information on the refugees of Wat Tham Krabok, see Grigoleit (2006).

${ }^{2}$ For further information on the impact of cultural capital on Southeast Asian parents and students, see Ngo (2006).

${ }^{3}$ Parents were very surprised that the school district commissioned a study to learn about their experiences with their children's education. The idea that school teachers and personnel wanted their opinion about the effectiveness of educational programs was unique in their experiences with schools in Thailand.

\section{References}

Bigelow, M., Ngo, B., Wahlstrom, K. L., Ingram, D., \& Whitehouse, B. (2005). A preliminary report on an evaluation of the Transitional Language Center program in the Saint Paul 
Ngo: The Affective Consequences of Cultural Capital

Public Schools. Minneapolis: Center for Applied Research and Educational Improvement, College of Education and Human Development, University of Minnesota.

Bourdieu, P. (1986). The forms of capital. In J. Richardson (Ed.), The handbook of theory and research in the sociology of education (pp. 241-258). New York: Greenwood Press.

Bourdieu, P. (1977). Cultural reproduction and social production. In J. Karabel \& A. H. Halsey (Eds.), Power and ideology in education (pp. 487-511). New York: Oxford University Press.

Carreon, D. P., Drake, C., \& Barton, A. C. (2005). The importance of presence: Immigrant parents’ school engagement experiences. American Educational Research Journal, 42(3), 465-498.

Collignon, F., Men, M., \& Tan, S. (2001). Finding ways in: Community-based perspectives on Southeast Asian family involvement with schools in a New England State. Journal of Education for Students Placed At Risk, 61(1\&2), 27-44.

Delgado-Gaitan, C. (2004). Involving Latino families in schools. Thousand Oaks, CA: Corwin Press.

Donnelly, N. (1994). Changing lives of refugee Hmong women. Seattle: University of Washington Press.

Emerson, R. M., Fretz, R. I., \& Shaw, L. L. (1995). Writing ethnographic fieldnotes. Chicago: University of Chicago Press.

Faderman, L. (1998) I begin my life all over: The Hmong and the American immigrant experience. Boston, MA: Beacon.

Fan, X. T., \& Chen, M. (2001). Parental involvement and students' academic achievement: A meta-analysis. Educational Psychology Review, 13, 1-22.

Fine, M. (1993). Apparent involvement: Reflections on parents, power, and urban public schools. Teachers College Record, 94(4), 682-729.

Gandara, P. (1995). Over the ivy walls: The educational mobility of low income Chicanos. New York: SUNY Press.

García Coll, C., Akiba, D., Palacios, N., Bailey, B., Silver, R., DiMartino, L., \& Chin, C. (2002). Parental involvement in children's education: Lessons from three immigrant groups. Parenting, Science and Practice, 2(3), 303-324.

Gibson, M. A. (1988). Accommodation without assimilation: Sikh immigrants in an American high school. Ithaca, NY: Cornell University Press.

Gonzalez, N., Moll, L., \& Amanti, C. (2005). Funds of knowledge: Theorizing practices in households, communities and classrooms. Mahwah, NJ: Lawrence Erlbaum Associates, Inc.

Grenfell, M. \& James, D. (1998). Bourdieu and education: Acts of practical theory. Bristol, PA: Falmer.

Grigoleit, G. (2006). Coming home: The integration of Hmong refugees from Wat Tham Krabok, Thailand into American society. Hmong Studies Journal, (7), 1-22.

Hang, M., Anderson, J., Walker, P., Thao, M., Chang, M., \& Hestness, L. (2004). American Paj Ntaub: Wat Tham Krabok team assessment report executive summary. St. Paul, MN.

Jeynes, W. H. (2003). A meta-analysis: The effects of parental involvement on minority children's academic achievement. Education and Urban Society, 35(2), 202-218.

Kibria, N. (1993) Family tightrope: The changing lives of Vietnamese Americans. Princeton, NJ: Princeton University Press. 
Krueger, R. \& Casey, M. A. (2000). Focus groups: A practical guide for applied research. Thousand Oaks, CA: Sage Publications, Inc.

Lareau, A. (1989). Home advantage: Social class parental intervention in elementary education. Philadelphia: Falmer Press.

Lareau, A. \& Horvat, E. M. (1999). Moments of social inclusion and exclusion: Race, class, and cultural capital in family-school relationships. Sociology of Education, 72(1), 37-53.

Lee, J-S. \& Bowen, N. K. (2006). Parent involvement, cultural capital, and the achievement gap among elementary school children. American Educational Research Journal, 43(2), 193218.

Lightfoot, D. (2004). "Some parents just don't care”: Decoding the meanings of parental involvement in urban schools. Urban Education, 39(1), 91-107.

López, G. (2001). The value of hard work: Lessons on parent involvement from an immigrant household. Harvard Educational Review, 71(3), 416-438.

Lopez, G. Scribner, J. D., \& Mahitivanichcha, K. (2001). Redefining parental involvement: Lessons from high-performing migrant-impacted schools. American Educational Research Journal, 38(2), 253-288.

Maira, S. (2002). Desis in the house: Indian American youth culture in New York City. Philadelphia, PA: Temple University Press.

McLeod, J. (1987). Ain't no makin' it: Aspirations and attainment in a low-income neighborhood. Boulder, CO: Westview.

Miles, M. B. \& Huberman, A. M. (1994). Qualitative data analysis: A sourcebook of new methods ( $2^{\text {nd }}$ ed.). Thousand Oaks, CA: Sage.

The Minneapolis Foundation (1999, Fall). Minnesota, nice or not? Minneapolis, MN: Author.

Moll, L. \& Gonzalez, N. (2003). Engaging life: A funds-of-knowledge approach to multicultural education. In J. A Banks, \& C. M. Banks (Eds.) Handbook of research on multicultural education (pp. 699-715). New York: Macmillan Publishing Company.

Ngo, B. (2006). Learning from the margins: Southeast and South Asian education in context. Race, Ethnicity and Education, 9(1), 51-65.

Ngo, B. (2000) Obstacles, miracles, and the pursuit of higher education: The experiences of Hmong American college students. Unpublished master's thesis, University of Wisconsin-Madison.

Olneck, M. (2000). Can multicultural education change what counts as cultural capital? American Educational Research Journal, 37(2), 317-348.

Phommsasouvanh, B. (1997). Social context of Lao people in the United States. In B. Te, M. T. Cordova, W. Walker-Moffat \& J. First (Eds.). Unfamiliar Partners: Asian parents and U.S. public schools (pp. 24-28). Boston, MA: National Coalition of Advocated for Students.

Pomerantz, E., Moorman, E., \& Litwack, S. (2007). The how, whom, and why of parents' involvement in children's academic lives: More is not always better. Review of Educational Research, 77(3), 373-410.

Robbins, D. (2000). Bourdieu and culture. Thousand Oaks, CA: Sage.

Smith-Hefner, N. J. (1999). Khmer American: Identity and moral education in a diasporic community. Berkeley: University of California Press.

Strauss, A., \& Corbin, J. (1998). Basics of qualitative research: Grounded theory procedures and techniques ( $2^{\text {nd }}$ ed.). Newbury Park, CA: Sage. 
Ngo: The Affective Consequences of Cultural Capital

Teranishi, R. T. (2004). Yellow and Brown: Emerging Asian American immigrant populations and residential segregation. Equity \& Excellence in Education, 37(3) 255-263.

Um, K. (1997). Resettlement into limbo: Implications for the schooling and education of Cambodian children. In B. Te, M. T. Cordova, W. Walker-Moffat \& J. First (Eds.). Unfamiliar Partners: Asian parents and U.S. Public Schools (29-35). Boston, MA: National Coalition of Advocates for Students.

Um, K. (2003). A Dream denied: Educational experiences of Southeast Asian American youth. Washington, DC: Southeast Asian Resource Action Center and Berkeley Southeast Asian Student Coalition.

U.S. Census Bureau (2000). 2000 Census of Population: General Populations Characteristics of the United States. Washington, DC: Author

Valdés, G. (1996). Con respeto: Bridging the distances between culturally diverse families and schools. New York: Teachers College Press.

Valenzuela (1999). Subtractive schooling: US Mexican youth and the politics of caring. New York: SUNY Press.

Vincent, J., Roscigno, J. W., \& Ainsworth, D. (1999). Race, cultural capital, and educational resources: Persistent inequalities and achievement returns. Sociology of education, 72(3), 158-178.

Wolcott, H. F. (1994). Transforming qualitative data: Description, analysis, and interpretation. Thousand Oaks, CA: Sage.

Zhou, M. \& C. L. Bankston (1998). Growing up American: How Vietnamese children adapt to life in the United States. New York: Russell Sage.

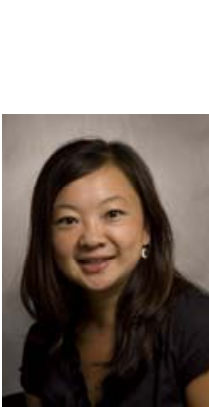

About the Author

Bic Ngo is an assistant professor of Curriculum and Instruction at the University of Minnesota. Her research examines "culture" and "difference" in the education of immigrant students, and the implications for theorizing immigrant identity, culturally relevant pedagogy, and anti-oppressive education. Her work has explored issues of culture and inequality in the education of Hmong American and Lao American students and families. 
Ngo: The Affective Consequences of Cultural Capital

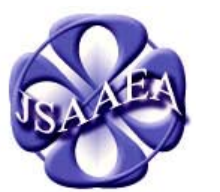

Volume 3 (2008)
Journal of Southeast Asian American

\section{Education \& Advancement}

A peer-reviewed scholarly journal published by the National Association for the Education \& Advancement of Cambodian, Laotian, and Vietnamese Americans (NAFEA)

\author{
Editor \\ Dr. Wayne E. Wright \\ University of Texas, San Antonio \\ Associate Editors \\ Dr. Chhany Sak-Humphry \\ University of Hawaii \\ Dr. KimOanh Nguyen-Lam \\ California State University, Long Beach \\ Book Review Editor \\ Vichet Chhuon \\ University of California-Santa Barbara \\ Creative Works Editor \\ Phouang Hamilton
}

Washington Office of Superintendent of Public Instruction

Special Advisor

Anne Frank

University of California, Irvine, Southeast Asian Archives

Editorial Assistant

Mariana Kuhl

University of Texas, San Antonio

Comments and questions for the editorial staff may be directed to jsaaea@lists.sis.utsa.edu

\title{
Editorial Review Board
}

\author{
Dr. Carl L. Bankston III \\ Tulane University \\ Dr. Phala Chea \\ Lowell Public Schools \\ Dr. Changming Duan \\ University of Missouri, Kansas City \\ Dr. Nancy H. Hornberger \\ University of Pennsylvania \\ Dr. Peter Nien-Chu Kiang \\ University of Massachusetts, Boston
}

\author{
Dr. Pollie Bith-Melander \\ Asian and Pacific Islander Wellness Center \\ Dr. George Chigas \\ University of Massachusetts, Lowell \\ Dr. Sophal Ear \\ U.S. Naval Postgraduate School \\ Dr. Samlong Inthaly \\ Minneapolis Public Schools \\ Dr. Kevin K. Kumashiro \\ University of Illinois, Chicago
}


Journal of Southeast Asian American Education and Advancement, Vol. 3 [2008], Iss. 1, Art. 4

Special Issue on Hmong Newcomers

Ngo: The Affective Consequences of Cultural Capital

Dr. Stacey Lee

University of Wisconsin, Madison

Dr. Sue Needham

California State University, Dominguez Hills

Dr. Max Niedzwiecki

Daylight Consulting Group

Dr. Clara Park

California State University, Northridge

Dr. Loan T. Phan

University of New Hampshire

Dr. Karen Quintiliani

California State University, Long Beach

Dr. Fay Shin

California State University, Long Beach

Dr. Yer J. Thao

Portland State University

Dr. Khatharya Um

University of California, Berkeley

Dr. Terrence G. Wiley

Arizona State University
Dr. David Chanpannha Ley

Montgomery County Public Schools

Dr. Bic Ngo

University of Wisconsin-Madison

Dr. Leakhena Nou

California State University, Long Beach

Dr. Mark Pfeifer

Texas A\&M University, Corpus Christi

Dr. Bounlieng Phommasouvanh

Minnesota Department of Education

Dr. Kalyani Rai

University of Wisconsin, Milwaukee

Dr. Nancy J. Smith-Hefner

Boston University

Dr. Myluong Tran

San Diego State University

Dr. Linda Trinh Vo

University of California, Irvine

Dr. Zha Blong Xiong

University of Minnesota

Dr. Kou Yang

California State University, Stanislaus

\section{Doctoral Student Editorial Review Board}

\section{Keo Chea}

University of Pennsylvania

Loan Dao

University of California, Berkeley

Ha Lam

Arizona State University

Vanna Som

Harvard University

Giang Pham

University of Minnesota

Tinou Tran

University of Houston, Texas

Phitsamay Sychitkokhong Uy

Harvard University
Vichet Chhuon

University of California, Santa Barbara

Annie BichLoan Duong

San Joaquin County Office of Education

Ravy Lao

University of California, Santa Barbara

Rassamichanh Souryasack

University of California, Santa Barbara

Layheng Ting

State University of New York, Albany

Loan Tran

University of California, Santa Barbara

Yang Sao Xiong

University of California, Los Angeles 